\title{
KARAKTERISTIK FISIOLOGIS DAN HASIL LATEKS TANAMAN KARET KLON GT1 DENGAN PERLAKUAN SISTEM SADAP PENDEK PADA PERKEBUNAN KARET RAKYAT
}

\author{
Physiological Characteristics and Latex Yields of Clone GT1 Rubber Plant with \\ Treatment of Shortly Tapping Systems In Smallholder Rubber Plantation
}

Yayuk PURWANINGRUM ${ }^{1}$, Yenni ASBUR ${ }^{1 *}$, Arif ANWAR $^{1}$, dan Febri Wira Nanta GINTING ${ }^{2}$

${ }^{1 *}$ Program Studi Agroteknologi

Fakultas Pertanian Universitas Islam Sumatera Utara Jalan Karya Wisata Gedung Johor Medan 20144 Sumatera Utara *Email : yenni.asbur@fp.uisu.ac.id

${ }^{2)}$ Mahasiswa Program Studi Agroteknologi, Fakultas Pertanian Universitas Islam Sumatera Utara Jalan Karya Wisata Gedung Johor Medan 20144 Sumatera Utara

Diterima : 26 Juli 2020 / Disetujui : 21 Desember 2020

\begin{abstract}
Indonesia has the largest rubber plantation area in the world, which is around 3.67 million $\mathrm{Ha}$ in 2017, but in terms of production it is only in second place after Thailand. This study was aimed to determine the physiological characteristics and latex yields of GT 1 clone rubber plants with treatment of shortly tapping systems in smallholder rubber plantations. The research was conducted in Halaban Village, Sidorejo Hamlet, Besitang Sub-District, Langkat District, North Sumatera Province, at of 500$700 \mathrm{~m}$ asl and ultisol soil types. The study used a non-factorial randomized block design with five replications and three treatments tapping system. The results showed that during January-June period, inorganic phosphate level was higher in the treatment of tapping grooves length as S/4 d3 ET 2.5\% compared to the 1 tapping grooves length of S/2 d3 ET 2.5\%, and S/ 8 d3 ET 2.5\%. The yield of latex with the tapping grooves length of $S / 2$ d3 ET was 2.5\% higher when the rubber plant leaves were optimal (January), and early leaves fall (February), while the latex yields in the early phase of new leaves (March-April), and leafflush (May-June), were higher in shorter tap length (S/ 8 d3 ET 2.5\%).
\end{abstract}

Keywords: Hevea brasiliensis; iorganic phosphate; sucrose; tapping groove length; thiol

Abstrak
Indonesia memiliki areal perkebunan
karet terluas di dunia, yaitu sekitar 3,67 juta
Ha pada tahun 2017, namun dari sisi
produksi hanya berada pada posisi kedua
setelah Thailand. Penelitian ini bertujuan
untuk mengetahui karakteristik fisiologis
dan hasil lateks tanaman karet klon GT 1
dengan perlakuan sistem sadap pendek di
perkebunan karet rakyat. Penelitian
dilaksanakan di Desa Halaban Dusun
Sidorejo Kecamatan Besitang Kabupaten
Langkat Provinsi Sumatera Utara dengan
ketinggian tempat 500-700 m dpl dan jenis
tanah ultisol. Penelitian menggunakan
Rancangan Acak Kelompok Non-faktorial
dengan lima ulangan dan tiga perlakuan
sistem sadap. Hasil penelitian menunjukkan
bahwa pada periode Januari-Juni 2019,
kadar fosfat anorganik (FA) lebih tinggi pada
perlakuan panjang alur sadap S/4 d3 ET
$2,5 \%$ dibandingkan dengan panjang alur
sadap S/2 d3 ET 2,5\%, dan S/8 d3 ET 2,5\%.
Hasil lateks dengan panjang alur sadap S/2


d3 ET 2,5\% lebih tinggi pada saat daun tanaman karet optimal (Januari), dan awal gugur daun (Februari), sedangkan hasil lateks pada fase awal daun baru (MaretApril), dan daun flush (Mei-Juni), lebih tinggi pada panjang alur sadap lebih pendek (S/8 d3 ET 2,5\%).

Kata kunci: fosfat anorganik; Hevea brasiliensis; panjang alur sadap; sukrosa; tiol

\section{PENDAHULUAN}

Indonesia memiliki areal perkebunan karet terluas di dunia, yaitu sekitar 3,67 juta Ha pada tahun 2017, namun dari sisi produksi hanya berada pada posisi kedua setelah Thailand yakni 3,23 juta ton. Menurut International Rubber Study Group [IRSG] (2007), produksi karet alam dunia pada tahun 2020 akan mencapai 13 juta ton dan Indonesia diperkirakan akan menjadi negara penghasil karet alam terbesar di dunia. Namun kenyataan menunjukkan bahwa Indonesia hanya mampu menghasilkan produksi karet tahun 2020 sebesar 3,55 juta ton (Direktorat Jenderal Perkebunan [Ditjenbun], 2020).

Peningkatan produksi dapat dilakukan melalui pengembangan areal baru maupun peningkatan produktivitas dengan meremajakan areal tanaman karet tua, dan rehabilitasi tanaman (Boerhendhy \& Amypalupy, 2011). Pengembangan karet di Indonesia terutama ditujukan pada perkebunan karet rakyat. Hal ini disebabkan perkebunan karet rakyat mempunyai peran yang sangat penting, tetapi masih banyak menghadapi masalah dan kendala, yaitu produktivitas karet rakyat masih relatif rendah dibandingkan dengan produktivitas perkebunan besar negara dan perkebunan swasta atau bahkan produktivitas karet rakyat di negara lain (Boerhendhy \& Amypalupy, 2011). Hal ini disebabkan perkebunan karet rakyat umumnya belum melaksanakan standar operasional yang sudah ditetapkan seperti pada perkebunanperkebunan besar swasta dan nasional dalam melakukan pemeliharaan pada tanaman karet dari awal sampai pemanenan. Pada pelaksanaan panen, petani karet rakyat tidak menggunakan sistem sadap dan tata guna panel yang benar (Sannia et al., 2013).

Pada tanaman karet, produksi yang diperoleh sangat dipengaruhi oleh sistem sadap yang diterapkan. Filosofi dalam pemanenan lateks pada tanaman karet adalah mengambil sebanyak mungkin dan sesering mungkin lateks yang ada dalam pembuluh lateks, namun tidak menyebabkan dampak keletihan fisiologis pada tanaman sehingga diperoleh produktivitas yang optimal (Sumarmadji, 2000).

Sistem sadap memiliki peranan penting untuk mengoptimalkan potensi produksinya. Setiap klon memiliki karakter fisiologis yang spesifik sehingga respon tanaman terhadap panjang alur sadap yang diaplikasikan juga beragam. Klon-klon dengan metabolisme tinggi cenderung responsif terhadap interval penyadapan tinggi namun kurang responsif terhadap pemberian stimulan. Klon-klon yang memiliki metabolisme rendah responsif terhadap pemberian stimulan namun memerlukan interval penyadapan yang lebih panjang (Woelan et al., 2012).

Berdasarkan karakter fisiologis, respons tanaman terhadap panjang alur sadap serta potensi produksinya umumnya dapat dibedakan menjadi klon slow starter (SS) dan quick starter (QS). Azwar dan Suhendry (1998) menyatakan bahwa klon QS dicirikan dengan puncak produksi yang diperoleh pada periode awal penyadapan, sedangkan puncak produksi klon SS cenderung diperoleh pada pertengahan siklus penyadapan.

Klon karet GT 1 adalah jenis klon SS yang umumnya digunakan sebagai bahan okulasi untuk batang bawah karena memiliki perakaran yang banyak serta kuat, namun memiliki produksi lateks yang tidak begitu banyak. Klon ini memiliki pertumbuhan lebih stabil, terutama pada curah hujan 2,000-3,000 $\mathrm{mm} /$ tahun (Sumarmadji et al., 2008). 
Produktivitas lateks secara berkesinambungan dapat dicapai apabila kulit pulihan yang produktif dapat diperoleh dan hubungan pembuluh lateks terhadap bidang sadap tidak teputus. Agar hal tersebut dapat dicapai, maka mutu penyadapan harus dikendalikan. Pengawasan sadapan bertujuan untuk menghindari terjadinya kesalahan penyadapan yang dapat berakibat rusaknya kulit atau kulit pohon habis sebelum waktunya. Harus disadari sepenuhnya bahwa penyadapan pada tanaman karet merupakan tindakan panen yang berkelanjutan hingga puluhan tahun. Oleh sebab itu, penerapan sistem sadap memerlukan suatu mekanisme panen di mana faktor panjang alur sadap diformulasikan sehingga dapat diterapkan secermat mungkin di lapangan (Priwanto \& Supijatno, 2009).

Dengan pertimbangan bahwa respon tanaman terhadap sistem sadap yang digunakan dapat berbeda pada setiap klonnya, maka penelitian ini bertujuan untuk mengetahui karakteristik fisiologis dan hasil lateks tanaman karet klon GT 1 dengan aplikasi sadap pendek.

\section{BAHAN DAN METODE}

Penelitian dilaksanakan di Desa Halaban Dusun Sidorejo Kecamatan Besitang Kabupaten Langkat Provinsi Sumatra Utara, dari periode bulan Januari hingga Juli 2019. Lokasi penelitian berada pada ketinggian 500-700 m dpl dan memiliki jenis tanah ultisol. Selanjutnya analisis fisiologi lateks dilaksanakan di Laboratorium Socfindo, Medan.

Penelitian menggunakan dua data, yaitu data primer dan data sekunder. Data sekunder adalah data curah hujan yang diambil dari BMKG (Badan Meteorologi Klimatologi dan Geofisika) pada 10 tahun terakhir, sedangkan data primer adalah data yang diamati selama penelitian. Data primer dianalisis menggunakan Rancangan Acak Kelompok non-faktorial lima ulangan dengan panjang alur sadap sebagai perlakuan. Perlakuan panjang alur sadap terdiri dari tiga taraf, yaitu panjang alur sadap setengah spiral (S/2 d3 ET 2,5\%, kontrol), panjang alur sadap seperempat spiral (S/4 d3 ET 2,5\%), dan panjang alur sadap seperdelapan spiral (S/8 d3 ET 2,5\%). Stimulan yang diberikan adalah stimulant cair etepon $2,5 \%$ dan penyadapan dilakukan pada panel BI (kulit pulihan). Secara lebih jelas, perlakuan pada penelitian diuraiakan sebagai berikut :

$\mathrm{S}_{1}$ (S/2 d3 ET 2,5\%): setengah spiral disadap 3 hari sekali dengan stimulant cair etepon $2,5 \%$

$\mathrm{S}_{2}$ (S/4 d3 ET 2,5\%): seperempat spiral disadap 3 hari sekali dengan stimulant cair etepon $2,5 \%$

$\mathrm{S}_{3}$ (S/8 d3 ET 2,5\%): seperdelapan spiral disadap 3 hari sekali dengan stimulant cair etepon $2,5 \%$

Tanaman yang digunakan dalam penelitian ini adalah tanaman karet rakyat klon GT 1 umur 19 tahun dengan jarak tanam $3 \mathrm{~m} \times 2,5 \mathrm{~m}$, lilit batang $60-75 \mathrm{~cm}$. Kriteria tanaman yang dipilih adalah tanaman dengan besar lilit batang antara $60-75 \mathrm{~cm}$ diukur pada ketinggian $130 \mathrm{~cm}$ dari permukaan tanah, kondisi kerapatan daun $60 \%$ dan tidak terkena penyakit jamur akar putih (JAP) dan KAS (Kering Alur Sadap). Penyadapan dilakukan pada pagi hari pukul 06.00-07.00 WIB, yaitu pada saat keadaan turgor pembuluh lateks masih tinggi sehingga keluarnya lateks dari pembuluh lateks yang terpotong berlangsung dengan aliran yang kuat.

Variabel yang diamati adalah hasil lateks dan fisiologi lateks. Hasil lateks diamati dengan melakukan penimbangan hasil satu hari setelah penyadapan agar lateks telah mengalami penggumpalan. Pengamatan hasil dilakukan 2 kali dalam seminggu sampai penelitian selesai.

Pengamatan fisiologis lateks dilakukan dengan cara lateks diambil dengan melukai kulit sesuai dengan perlakuan panjang alur sadap. Lateks disimpan dan dikumpulkan di dalam botol film plastik kemudian disimpan di dalam kotak es. Lateks sebanyak $1 \mathrm{~mL}$ dimasukkan ke dalam $9 \mathrm{~mL}$ larutan 2,5\% trichloriacetic acid (TCA). Kemudian lateks dianalisis menggunakan batang gelas untuk mengeluarkan serumnya dan disimpan pada suhu $4{ }^{\circ} \mathrm{C}$ hingga digunakan. 
Fisiologi lateks yang diamati adalah kandungan sukrosa, fosfat anorganik (FA) dan Tiol. Analisis kandungan sukrosa dilakukan dengan cara sebanyak $\pm 150 \mu \mathrm{L}$ sampel ditambah TCA 2,3\% hingga volume total $500 \mu \mathrm{L}$, ditambah pereaksi antrone 3 $\mathrm{mL}$ (Anthrone 0,1 g ditambahkan ke dalam larutan sulfat $100 \mathrm{~mL}$ dan divorteks). Campuran dipanaskan dengan direndam pada air mendidih selama 15 menit, lalu didinginkan dalam air. Dehidrasi sukrosa dalam asam sulfat pekat $\left(\mathrm{H}_{2} \mathrm{SO}_{4} 70 \%\right)$ dan pemanasan akan memberikan turunan furfural yang bereaksi dengan anthrone menghasilkan warna biru yang selanjutnya diukur absorbannya pada panjang gelombang $627 \mathrm{~nm}$ dengan Spektrofotometer Beckman DU 650.

Analisis FA dilakukan dengan menambahkan TCA 2,3\% ke dalam $\pm 0,3 \mathrm{~mL}$ sampel hingga volume $1,5 \mathrm{~mL}$ (faktor pengenceran 1,5:0,3 $\mathrm{mL}$ ). $\mathrm{Ke}$ dalam campuran tersebut ditambahkan $1 \mathrm{~mL}$ pereaksi campur $\left(\mathrm{FeSO}_{4} 5 \mathrm{~g}+50 \mathrm{~mL}\right.$ Aquades = larutan stok Molibdat $10 \mathrm{~mL}$ dan ditera hingga $100 \mathrm{~mL}$ ) dan divorteks. Campuran diinkubasi selama 10 menit pada suhu kamar, kemudian absorbansi diukur pada panjang gelombang $750 \mathrm{~nm}$.

Analisis Tiol dilakukan dengan mengambil sebanyak $\pm 1,5 \mathrm{~mL}$ sampel ditambah TCA 2,5\% hingga volume 1,5 mL kemudian ditambahkan pereaksi DTNB 10

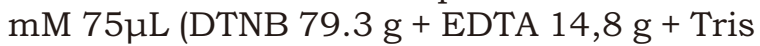
$0,5 \mathrm{M} 5 \mathrm{~mL}$ dan aquades $5 \mathrm{~mL}$ diaduk, $\mathrm{pH}$ ditepatkan 6,5 dengan TCA 2,5\% dan volume ditepatkan $20 \mathrm{~mL}$ ), ditambah 1,5 mL Buffer Tris $0,5 \mathrm{M}(30,3 \mathrm{~g}$ Tris dilarutkan dalam 500 $\mathrm{mL}$ Aquades) dan divorteks, dilanjutkan dengan inkubasi pada suhu kamar selama 30 menit. Absorbansi dibaca pada panjang gelombang $421 \mathrm{~nm}$ dengan spektrofotometer Beckman DU 650 atau diukur dari serum TCA berdasarkan prinsip reaksinya dengan asam dithiobis-nitrobenzoat (DTNB) untuk membentuk TNB yang berwarna kuning yang terabsorbsi pada panjang gelombang $412 \mathrm{~nm}$ dengan spektrofotometer Beckman DU 650.

Data-data yang diperoleh selanjutnya dianalisis menggunakan sidik ragam (ANOVA); pengujian lebih lanjut menggunakan Beda Nyata Terkecil (BNT) pada tingkat signifikan 5\%. Data dianalisis menggunakan Statistical Analysis System (SAS) Software 9.1.

\section{HASIL DAN PEMBAHASAN}

\section{Fisiologi Lateks}

Sistem eksploitasi dapat menyebabkan cekaman fisiologi terhadap tanaman karet, sehingga memerlukan parameter fisiologi melalui diagnosis lateks guna mengetahui pengaruh sistem eksploitasi terhadap kondisi kesehatan tanaman. Karakter fisiologi pada tanaman karet erat hubungannya dengan kemampuan tanaman dalam mensintesis asimilat menjadi bahan pembentuk lateks. Karakter fisiologi yang sangat penting dalam pembentukan lateks di antaranya adalah kandungan sukrosa, fosfat anorganik (FA), dan kadar tiol.

Hasil analisis sidik ragam menunjukkan bahwa panjang alur sadap berpengaruh nyata terhadap kadar sukrosa dan FA lateks klon GT 1, tetapi berpengaruh tidak nyata terhadap kadar tiol lateks klon GT 1. Hasil analisis dirangkum pada Tabel 1. Tabel 1 menunjukkan bahwa panjang alur sadap berpengaruh nyata terhadap kadar sukrosa lateks klon GT 1. Semakin pendek panjang alur sadap maka kadar sukrosa akan semakin tinggi. Kadar sukrosa lateks tertinggi diperoleh pada perlakuan panjang alur sadap pendek S/4 d3 ET 2,5\% $\left(\mathrm{S}_{2}\right)$, diikuti oleh perlakuan S/8 d3 ET 2,5\% $\left(\mathrm{S}_{3}\right)$ danS / 2 d3 ET 2,5\% ( $\left.\mathrm{S}_{1}\right)$, yaitu berturut-turut $10,50 \mathrm{mM}, 10,06 \mathrm{mM}$, dan 4,26 mM. Menurut Wibowo dan Sumarmadji (2005), semakin pendek panjang alur sadap akan meningkatkan laju tekanan aliran lateks dan gangguan terhadap angkutan hasil asimimilat akan semakin kecil. Hasil penelitian Herlinawati dan Kuswanhadi (2012) serta Purwaningrum et al. (2016) juga menunjukkan bahwa sistem sadap pendek mampu memobilisasi karbohidrat sehingga kandungan sukrosa meningkat.

Menurut Sumarmadji et al. (2006), kadar sukrosa lateks pada tanaman karet dewasa yang dapat disadap berkisar antara 
3,75-6,91 mM. Kadar sukrosa hasil penelitian ini berkisar 4,26-10,50 mM. Hal ini disebabkan klon GT 1 merupakan klon dengan metabolisme lambat (slow starter clone), sehingga tingkat metabolisme lateksnya lebih rendah dibandingkan klon karet dengan metabolisme tinggi (quick starter clone) ('Siregar et al., 2008). Jacob et al. (1989) menyatakan bahwa dinamika kadar sukrosa pada lateks sangat dipengaruhi oleh tingkat metabolisme dalam jaringan. Kuswanhadi et al. (2009) menyatakan bahwa pada tanaman dewasa, kadar sukrosa yang rendah mengindikasikan bahwa metabolisme bahan asimilat sangat intensif, sehingga cadangan karbohidrat terkuras untuk produksi karet. Sebaliknya, kadar sukrosa yang tinggi menunjukkan kurang aktifnya metabolisme tanaman. Kadar sukrosa yang tinggi bisa juga berarti bahwa sel latisifer sudah tidak berfungsi lagi atau mengalami degenerasi.

Kadar FA (fosfat anorganik) menggambarkan ketersediaan energi pada sel-sel pembuluh lateks untuk mengubah sukrosa menjadi partikel karet (Sumarmadji \& Tistama, 2004). Hasil analisis statistik menunjukkan bahwa panjang alur sadap berpengaruh nyata terhadap kadar FA lateks klon GT 1 (Tabel 1). Panjang alur sadap S/4 d3 ET 2,5\% $\left(\mathrm{S}_{2}\right)$ menghasilkan kadar FA yang lebih tinggi dibandingkan dengan panjang alur sadap $\mathrm{S} / 2$ d3 ET 2,5\% $\left(\mathrm{S}_{1}\right)$ dan $\mathrm{S} / 8 \mathrm{~d} 3$ ET $2,5 \%\left(\mathrm{~S}_{3}\right)$, yaitu berturut-turut $25,90 \mathrm{mM}$, 25,48 mM, dan 21,46 mM. Kadar FA pada penelitian ini tergolong tinggi. Menurut Rachmawan dan Sumarmadji (2007), kandungan fosfat anorganik yang optimal pada tanaman karet berkisar antara 10-20 $\mathrm{mM}$.

Lebih tingginya kadar FA pada panjang alur sadap S/4 d3 ET 2,5\% $\left(\mathrm{S}_{2}\right)$ disebabkan irisan sadap lebih pendek, tekanan turgor dan gradien pada sel lateks lebih dipertahankan dan tidak terjadi pembatasan daerah drainase (Southorn \& Gomez, 1970), sehingga aktivitas metabolisme tanaman karet yang diberikan perlakusan sistem sadap S/4 d3 ET 2,5\% $\left(\mathrm{S}_{2}\right)$ meningkat yang tercermin dari lebih tingginya kadar FA pada perlakuan panjang alur sadap S/ 4 d3 ET 2,5\% $\left(\mathrm{S}_{2}\right)$ dibandingkan dengan perlakuan panjang alur sadap lainnya. Hal ini sesuai dengan pendapat Lacote et al. (2010) yang menyatakan bahwa intensitas aktivitas metabolisme dalam pembuluh lateks dicerminkan oleh kadar FA.

Peningkatan kadar FA menunjukkan peningkatan aktivitas metabolisme dalam sel lateks (Soumahin et al., 2009). Secara umum, semakin meningkat kadar FA maka akan semakin menurun kadar sukrosa karena sukrosa diubah menjadi lateks. Lacote et al. (2010) menyatakan bahwa kadar FA menunjukkan kemampuan kecepatan suatu klon merubah sukrosa menjadi lateks. Namun, hasil penelitian ini menunjukkan bahwa kadar FA yang tinggi

Tabel 1. Fisiologi lateks klon GT 1 dengan perlakuan panjang alur sadap Table 1. Physiology of latex GT 1 clones with tapping groove length treatment

\begin{tabular}{cccc}
\hline & & \multicolumn{2}{c}{$\begin{array}{c}\text { Fisiologi lateks } \\
\text { Latex physiology }\end{array}$} \\
\cline { 2 - 4 } Treatmens & $\begin{array}{c}\text { Sukrosa } \\
\text { Sucrose } \\
(\mathrm{mM})\end{array}$ & $\begin{array}{c}\text { Fosfat anorganic } \\
\text { Inorganic phosphate } \\
(\mathrm{mM})\end{array}$ & $\begin{array}{c}\text { Tiol } \\
\text { Thiol } \\
(\mathrm{mM})\end{array}$ \\
\hline $\mathrm{S}_{1}$ (S/2 d3 ET 2,5\%) & $4,26 \mathrm{~b}$ & $25,48 \mathrm{a}$ & 0,92 \\
$\mathrm{~S}_{2}$ (S/4 d3 ET 2,5\%) & $10,50 \mathrm{a}$ & $25,90 \mathrm{a}$ & 1,10 \\
$\mathrm{~S}_{3}$ (S/8 d3 Et 2,5\%) & $10,06 \mathrm{a}$ & $21,46 \mathrm{~b}$ & 1,04 \\
\hline
\end{tabular}

Keterangan: Angka yang diikuti oleh huruf yang berbeda pada kolom yang sama menunjukkan berbeda nyata berdasarkan uji BNT dengan taraf 5\%. Angka tanpa notasi pada kolom yang sama menunjukkan berbeda tidak nyata berdasarkan uji BNT dengan taraf $5 \%$

Remaks: Number followed with different letter at the same coloum showed significantly different basedon BNT at 5\% level. Number without notation at the same coloum showed not significantly different based on BNT at 5\% level. 
diikuti oleh kadar sukrosa yang tinggi pula (Tabel 1). Klon GT 1 tergolong klon metabolisme rendah (slow starter clone) dengan kadar sukrosa dan FA tinggi, hal ini disebabkan pengolahan sukrosa menjadi lateks berlangsung lambat, sehingga kadar sukrosa tinggi karena lambat digunakan untuk mendukung proses pembentukan lateks, dan lebih banyak ke pertumbuhan vegetatif. Menurut Sumarmadji et al. (2008), klon GT1 menunjukkan pertumbuhan vegetatif lebih jagur dengan lilit batang tegap dan kulit pulihan tebal. Sejalan dengan hasil penelitian Herlinawati dan Kuswanhadi (2013) yang menunjukkan bahwa hubungan antara kadar FA dengan produksi bersifat positif, namun kadar FA dan sukrosa mempunyai korelasi negatif karena peningkatan metabolisme tidak diikuti dengan peningkatan konsumsi sukrosa.

Tabel 1 menunjukkan bahwa perlakuan panjang alur sadap berpengaruh tidak nyata terhadap kadar tiol klon GT 1. Namun ada kecenderungan perlakuan panjang alur sadap lebih pendek $\mathrm{S} / 4 \mathrm{~d} 3 \mathrm{ET}$ $2,5 \% \quad\left(\mathrm{~S}_{2}\right)$ dan $\mathrm{S} / 8$ d3 $\quad$ ET $2,5 \% \quad\left(\mathrm{~S}_{3}\right)$ menghasilkan kadar tiol lebih tinggi dibandingkan dengan perlakuan panjang alur sadap $\mathrm{S} / 2$ d3 ET $2,5 \% \quad\left(\mathrm{~S}_{1}\right)$, yaitu berturut-turut $1,10 \mathrm{mM}, 1,04 \mathrm{mM}$, dan 0,92 mM. Hasil penelitian Sumarmadji (2009) menunjukkan bahwa tidak ada perbedaan yang nyata antara irisan pendek dengan irisan panjang terhadap kadar tiol lateks. Sedangkan menurut Junaidi (2013), kadar tiol berbanding terbalik dengan intensitas eksploitasi. Semakin tinggi intensitas eksploitasi, maka semakin rendah kadar tiol. Kandungan tiol dipengaruhi juga oleh beberapa faktor di antaranya sistem eksploitasi, variasi musiman (musim gugur daun, awal daun baru, daun flush) dan umur tanaman.

Kadar tiol yang optimal berkisar antara 0,4-0,9 mM (Sumarmadji \& Tistama, 2004). Peningkatan intensitas eksploitasi berpengaruh pada peningkatan kadar tiol, tetapi apabila intensitas eksploitasi berlebihan maka kadar tiol menjadi rendah kembali. Tiol merupakan parameter kontrol dalam hubungannya dengan kering alur sadap (KAS) (Jacob et al., 1989). Eksploitasi berlebihan pada tanaman karet dapat menyebabkan timbulnya KAS (Herlinawati \& Kuswanhadi, 2013; Woelan et al., 2013).
Hasil penelitian ini menunjukkan bahwa kadar tiol berkisar antara 0,94-1,00 $\mathrm{mM}$ yang berarti bahwa kadar tiol sudah melebihi kadar optimal. Kondisi ini disebabkan waktu penelitian berkisar pada variasi musiman daun karet (Januari-Juni), di mana tanaman karet mengalami musim gugur daun, awal daun baru, dan daun flush yang menyebabkan tanaman berupaya menjaga keseimbangan antara pembentukan asimilat untuk lateks yang dipanen dengan lateks yang terbentuk kembali dan asimilat untuk pertumbuhan daun, sehingga tanaman mengalami stres atau kelelahan yang ditunjukkan dengan tingginya kadar tiol (Siswanto, 1999).

\section{Hasil Lateks}

Hasil analisis sidik ragam menunjukkan bahwa perlakuan panjang alur sadap berpengaruh nyata terhadap hasil lateks klon GT 1 pada bulan Januari, Februari, dan April, tetapi berpengaruh tidak nyata terhadap hasil lateks klon GT 1 pada bulan Maret, Mei, dan Juni sebagaimana diuraikan pada Tabel 2.

Tidak adanya pengaruh nyata perlakuan panjang alur sadap terhadap hasil lateks klon GT 1 pada bulan Maret, Mei, dan Juni sejalan dengan hasil penelitian Aidi-Daslin (2014) yang menunjukkan bahwa hasil lateks tidak dipengaruhi oleh panjang alur sadap, tetapi lebih dipengaruhi oleh intensitas sadap. Hal ini disebabkan klon GT 1 merupakan klon metabolisme rendah (slow starter) yang kurang responsif terhadap panjang alur sadap dan intensitas penyadapan, tetapi responsif terhadap pemberian stimulan (Woelan et al., 2012).

Tabel 2 menunjukkan pula bahwa panjang alur sadap berpengaruh nyata terhadap hasil lateks klon GT 1 pada bulan Januari, Februari, dan April. Pada bulan Januari, hasil lateks tertinggi pada perlakuan panjang alur sadap S/4 d3 ET $2,5 \%\left(\mathrm{~S}_{2}\right)$, diikuti oleh panjang alur sadap $\mathrm{S} / 8 \mathrm{~d} 3 \mathrm{ET} 2,5 \%\left(\mathrm{~S}_{3}\right)$, dan panjang alur sadap $\mathrm{S} / 2$ d3 ET 2,5\% $\left(\mathrm{S}_{1}\right)$, yaitu berturut-turut $9,00 \mathrm{~g} / \mathrm{p} / \mathrm{s}, 7,14 \mathrm{~g} / \mathrm{p} / \mathrm{s}$, dan $7,00 \mathrm{~g} / \mathrm{p} / \mathrm{s}$.

Pada bulan Februari tanaman karet sudah mulai memasuki musim gugur daun, sehingga penyadapan dengan panjang alur sadap yang lebih panjang (S/2 d3 ET 2,5\%) 
Tabel 2. Hasil lateks klon GT 1 dengan perlakuan panjang alur sadap Table 2. Latex yield of GT 1 clone with tapping groove length treatment

\begin{tabular}{lcccccc}
\hline & \multicolumn{5}{c}{$\begin{array}{c}\text { Hasil lateks } \\
\text { (g/p/s) } \\
\text { Latex yields } \\
\text { Perlakuan } \\
\text { Treatments }\end{array}$} \\
\cline { 2 - 7 } & & \multicolumn{5}{c}{$\mathrm{g} / \mathrm{t})$} \\
\cline { 2 - 7 } & Januari & Februari & Maret & April & Mei & Juni \\
& January & February & March & April & May & June \\
\hline $\mathrm{S}_{1}$ (S/2 d3 ET 2,5\%) & $7,00 \mathrm{~b}$ & $7,88 \mathrm{a}$ & 2,33 & $1,11 \mathrm{~b}$ & 1,97 & 3,11 \\
$\mathrm{~S}_{2}$ (S/4 d3 ET 2,5\%) & $9,00 \mathrm{a}$ & $4,89 \mathrm{~b}$ & 2,65 & $1,69 \mathrm{a}$ & 2,36 & 3,50 \\
$\mathrm{~S}_{3}$ (S/8 d3 ET 2,5\%) & $7,14 \mathrm{ab}$ & $4,51 \mathrm{~b}$ & 2,21 & $1,91 \mathrm{a}$ & 2,89 & 4,27 \\
\hline
\end{tabular}

Keterangan: Angka yang diikuti oleh huruf yang berbeda pada kolom yang sama menunjukkan berbeda nyata berdasarkan uji BNT dengan taraf 5\%. Angka tanpa notasi pada kolom yang sama menunjukkan berbeda tidak nyata berdasarkan uji BNT dengan taraf $5 \%$

Remaks: Number followed with different letter at the same coloum showed significantly different basedon BNT at 5\% level. Number without notation at the same coloum showed not significantly different based on BNT at 5\% level.

akan lebih banyak menghasilkan lateks dibandingkan dengan panjang alur sadap yang lebih pendek (S/4 d3 ET 2,5\% dan S/8 d3 ET 2,5\%) (Tabel 2). Sejalan dengan hasil penelitian Woelan et al. (2012) yang menunjukkan bahwa tanaman karet klon metabolisme rendah cenderung mengalami penurunan hasil lateks dengan menurunnya panjang irisan sadap. Pada bulan April, hasil lateks lebih tinggi pada panjang alur sadap lebih pendek, yaitu S/ 8 d3 ET 2,5\% $\left(\mathrm{S}_{3}\right)$ dan $\mathrm{S} / 4$ d3 ET 2,5\% $\left(\mathrm{S}_{2}\right)$ dibandingkan dengan panjang alur sadap $\mathrm{S} / 2$ d3 ET 2,5\% $\left(\mathrm{S}_{1}\right)$. Menurut Southorn dan Gomez (1970), irisan sadap yang lebih pendek menyebabkan tekanan turgor dan gradien pada sel lateks akan lebih dipertahankan dan tidak menyebabkan terjadinya pembatasan daerah drainase, sehingga aktivitas metabolisme tanaman karet yang diberikan perlakusan sistem sadap $\mathrm{S} / 8 \mathrm{~d} 3 \mathrm{ET} 2,5 \%\left(\mathrm{~S}_{3}\right)$ dan $\mathrm{S} / 4$ d3 ET 2,5\% $\left(\mathrm{S}_{2}\right)$ meningkat dan lateks yang dihasilkan juga lebih tinggi.

Hasil lateks klon GT 1 mengalami fluktuasi selama penelitian dari JanuariJuni yang disajikan pada Gambar 1. Gambar 1 menunjukkan bahwa hasil lateks klon GT

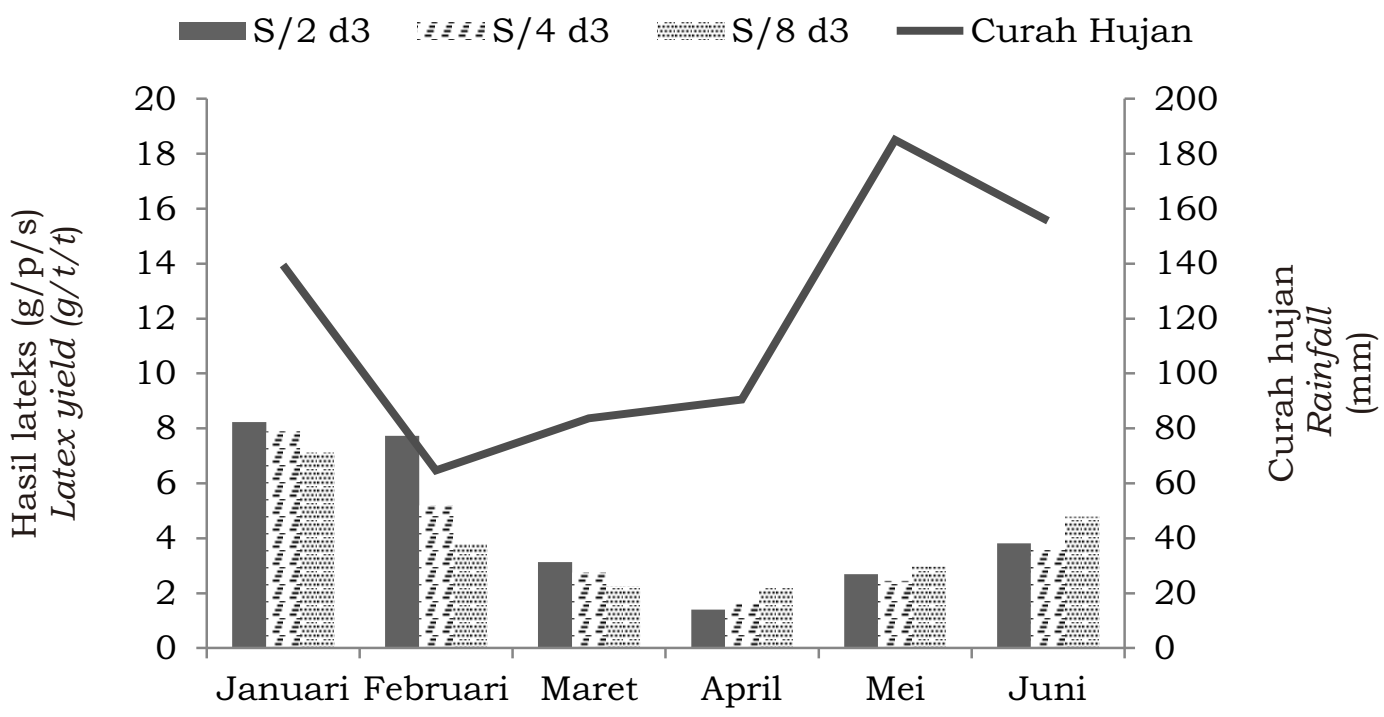

Gambar1. Hasil lateks klon GT 1 dengan perlakuan panjang alur sadap dan curah hujan pada bulan Januari-Juni 2019

Figure 1. Latex yields GT 1 clone with tapping groove length treatment and rainfall in JanuaryJune 2019 
1 bulan Januari lebih tinggi dibandingkan dengan bulan Februari-Juni. Hal ini disebabkan pada bulan Januari tanaman karet masih dalam fase tajuk daun sempurna dan curah hujan juga lebih tinggi $(139,4 \mathrm{~mm})$, sedangkan pada bulan Februari-Juni tajuk daun karet mengalami gugur daun, awal daun baru, dan daun flush, sehingga lateks yang dihasilkan juga rendah walaupun pada bulan Mei dan Juni curah hujan lebih tinggi dari bulan Januari, yaitu berturut-turut $184,9 \mathrm{~mm}$ dan 155,6 $\mathrm{mm}$. Menurut ${ }^{\mathrm{b}}$ Siregar (2008), seiring dengan perubahan musim, tanaman karet secara siklik periodik mengalami gugur daun pada musim kemarau dan pembentukan daun sempurna terjadi pada saat musim hujan. Kondisi tersebut sangat mempengaruhi produktivitas tanaman.

Bulan Februari dan Maret, tanaman karet klon GT 1 mulai mengalami penurunan hasil lateks (Gambar 1). Hal ini disebabkan pada bulan Februari tanaman karet sudah mulai memasuki musim gugur daun dan curah hujan yang rendah yaitu berturutturut $64,7 \mathrm{~mm}$ dan $83,6 \mathrm{~mm}$, sehingga fotosintesis terganggu yang berakibat pada penurunan hasil lateks. ${ }^{a}$ Siregar et al. (2007) menyatakan bahwa perontokan daun terdiri atas tiga tahap, yaitu (1) inisisasi perontokan daun melalui sinyal internal perontokan, (2) induksi perontokan melalui sintesis hormon pada daun, dan (3) perontokan daun yang didahului perubahan-perubahan biokimia, anatomi, dan fisiologi. Perontokan daun dapat terjadi secara serempak atau bertahap. Lebih lanjut ${ }^{a}$ Siregar et al. (2007) menyatakan bahwa perontokan daun merupakan aklimatisasi saat periode kering. Perontokan daun penting dalam rangka homeostatik, untuk mempertahankan keseimbangan antara tajuk dengan bagian tanaman lain dan keseimbangan pohon dengan lingkungan.

Penurunan hasil lateks paling banyak terjadi pada bulan April (Gambar 1) walaupun pada bulan tersebut tanaman karet sudah mulai memasuki fase pembentukan daun baru (daun flush) dan curah hujan yang lebih tinggi dari dari bulan Maret, yaitu 90,5 mm. Menurut Thomas dan Boerhendhy (1988), klon GT 1 memiliki tanggap yang tidak sama dalam hal defisit air. Klon GT 1 menggugurkan daunnya pada periode setelah defisit air. Penurunan produksi paling besar terjadi pada waktu pembentukan daun baru. Hal ini disebabkan klon GT 1 dengan tipologi klon metabolisme lambat masih mempunyai cadangan asimilat pada saat gugur daun yang dapat digunakan untuk pembentukan lateks, sedangkan pada saat daun memasuki fase pembentukan daun baru, cadangan asimilat sudah habis akibat berkurangnya asimilat yang terbentuk pada saat gugur daun, sehingga lateks yang dihasilkan menurun.

Pada bulan Mei dan Juni hasil lateks klon GT 1 mulai mengalami peningkatan kembali (Gambar 1). Hal ini disebabkan sejalan dengan perubahan curah hujan, daun-daun tumbuh kembali dan berfungsi sebagai sumber yang menghasilkan asimilat bagi pertumbuhan tajuk dan pembentukan lateks. Sejalan dengan hasil penelitian ${ }^{\mathrm{b}}$ Siregar (2008), curah hujan yang rendah atau pada saat musim kering menyebabkan tanaman karet secara alami beradaptasi dengan cara menggugurkan daunnya. Sejalan dengan peubahan curah hujan maka daun-daun tanaman karet akan tumbuh kembali, sehingga sukrosa sebagai sumber asimilat bagi pertumbuhan tajuk dan lateks akan meningkat pula.

\section{KESIMPULAN}

Pada periode Januari sampai dengan Juni, hasil penelitian menunjukkan bahwa kadar fosfat anorganik lebih tinggi pada perlakuan panjang alur sadap S/4 d3 ET $2,5 \%\left(\mathrm{~S}_{2}\right)$ dibandingkan dengan panjang alur sadap $\mathrm{S} / 2$ d3 ET $2,5 \%\left(\mathrm{~S}_{1}\right)$ dan $\mathrm{S} / 8$ d3 ET $2,5 \%\left(\mathrm{~S}_{3}\right)$. Hasil lateks dengan panjang alur sadap S/2 d3 ET 2,5\% ( $\left.\mathrm{S}_{1}\right)$ lebih tinggi pada saat daun tanaman karet optimal (Januari), dan awal gugur daun (Februari), sedangkan hasil lateks pada fase awal daun baru (Maret-April), dan daun flush (Mei-Juni), lebih tinggi pada panjang alur sadap lebih pendek (S/8 d3 ET 2,5\%).

\section{DAFTAR PUSTAKA}

Aidi-Daslin. (2014). Produktivitas klon karet IRR Seri 100 dan 200 pada berbagai agroklimat dan sistem sadap. Warta Perkaretan, 33(1), 11-18. https:// doi.org/10.22302/ppk.wp.v33i1.45 
Azwar, R., \& Suhendry, I. (1998). Kemajuan pemuliaan karet dan dampaknya terhadap peningkatan produktivitas. Prosiding Lokakarya Nasional Pemuliaan 1998 dan Diskusi Nasional Prospek Karet Alam Abad 21 (p.51-64). Medan, Indonesia: Pusat Penelitian Karet.

Boerhendhy, I., \& Amypalupy, K. (2011). Optimalisasi produktivitas karet melalui penggunaan bahan tanam, pemeliharaan, sistem eksploitasi, dan peremajaan tanaman. Jurnal Litbang Pertanian, 30(1), 23-30. https:// dx.doi.org/10.21082/jp3.v30n1.2011 .p23-30

Direktorat Jenderal Perkebunan. (2020). Produksi Karet Menurut Provinsi di Indonesia, 2016-2020. Jakarta, Indonesia: Direktorat Jenderal Perkebunan.

Herlinawati, E., \& Kuswanhadi. (2012). Pengaruh penggunaan stimulan gas terhadap produksi dan karakter fisiologi klon karet BPM 24. Jurnal Penelitian Karet, 30(2), 100-107. https:/ /dx.doi.org/ 10.22302/ppk.jpk .v30i2.126

Herlinawati, E., \& Kuswanhadi. (2013). Alternatif sistem sadap klon RRIC 100 mulai buka sadap. Jurnal Penelitian Karet, 31(2), 102-109. https:// dx.doi.org/10.22302/ppk.jpk.v31i2.1 37

International Rubber Study Group. (2007). The World Rubber Industry. Singapore: IRSG

Jacob, J.L., Prevot, J.C., \& Kekwick, R.G.O. (1989). General metabolism Hevea brasiliensis latex. In J. d'Auzac and $\mathrm{H}$. Chrestin (Eds). Physiology of Rubber Tree Latex. Boca Raton, USA : CRC Press. https://doi.org/10.1201/ 9781351075695

Junaidi. (2013). Hasil Uji coba Aplikasi Stimulan Gas LET I System untuk Meningkatkan Produktivitas Tanaman Karet di Kebun Jalupang PTP Nusantara VIII. Medan, Indonesia: Penelitian Sungei Putih, Pusat Penelitian Karet.
Kuswanhadi., Sumarmadji., Karyudi., \& Siregar, T.H.S. (2009). Optimasi produksi klon karet melalui sistem eksploitasi berdasarkan metabolisme lateks. Prosiding Lokakarya Nasional Pemuliaan tanaman karet 2009. Yogyakarta, Indonesia: Pusat Penelitian Karet.

Lacote, R., Gabla, O., Obouayeba, S., Eschbach, J.M., Rivano, F., Dian, K., \& Gohet, E. (2010). Long term effect of ethylene stimulation on the yield of rubber trees is linked to latex cell biochemistry. Field Crops Research, 115(1), 94-98. https://doi.org/ 10.1016/j.fcr.2009.10.007

Priwanto., \& Supijatno. (2009). Penyadapan karet (Hevea brasilliensis Muell Arg.) di Tulung Gelam Estate, PT PP London Sumatera Indonesia, Tbk. Kabupaten Ogan Komering Ilir, Sumatera Selatan. Makalah Seminar Departemen Agronomi dan Hortikultura. Bogor, Indonesia: Institut Pertanian Bogor.

Purwaningrum, Y., Napitupulu, J.A., Hanum, C., \& Siregar, T.H.S. (2016). Pengaruh sistem eksploitasi terhadap produksi karet pada klon PB 260. Jurnal Pertanian Tropik, 3(1), 62-69. https://doi.org/ 10.32734/jpt.v3i1.29 58

Rachmawan, A., \& Sumarmadji. (2007). Kajian karakter fisiologi dan sifat karet klon PB 260 menjelang buka sadap. Jurnal Penelitian Karet, 25(2), 59-70.

Sannia, B., Ismono, R.H., \& Viantimala, B. (2013). Hubungan kualitas karet rakyat dengan tambahan pendapatan petani di desa program dan nonprogram. Jurnal Ilmu-Ilmu Agribisnis, 1(1), 36-43. http://dx.doi.org/ 10.23960/jiia.v1i1.\%25p

Siregar, T.H.S., Tohari, H., Hartiko., \& Karyudi. (2007). Dinamika perontokan daun pohon karet dan hasil lateks: Jumlah daun rontok dan hasil lateks. Jurnal Penelitian Karet, 25(1), 45-58 
Siregar, T.H.S., Junaidi., Sumarmadji., Siagian, N., \& Karyudi. (2008). Perkembangan penerapan rekomendasi sistem eksploitasi tanaman karet di Perusahaan Besar Negara. Prosiding Lokakarya Nasional Agribisnis Karet. Yogyakarta, Indonesia: Pusat Penelitian Karet.

Siregar, T.H.S. (2008). Dinamika kerontokan daun pohon karet (Hevea brasiliensis Muell Agr) dan hasil lateks. [Disentrasi]. Yogyakarta, Indonesia: Universitas Gajah Mada.

Siswanto. (1999). Kunci keberhasilan penyembuhan KAS pada tanaman karet dengan aplikasi NoBB. Warta Penelitian Bioteknologi Perkebunan, 5(1), 12-19.

Soumahin, E.F., Obouayeba, S., \& Anno, P.A. (2009). Low tapping frequency with hormonal stimulation on Hevea brasiliensis clone PB 217 reduces tapping manpower requirement. Journal of Animal and Plant Sciences, 2(3), 109-117.

Southorn, W.A., \& Gomez, J.B. (1970). Latex flow studies VII. Influence of lenght of tapping cut on latex flow pattern. J. Rubb. Res. Inst. Malaya, 23(1), 15-22.

Sumarmadji. (2000). Sistem eksploitasi tanaman karet yang spesifikdiskriminatif. Warta Pusat Penelitian Karet, 19 (1-3).

Sumarmadji., \& Tistama, R. (2004). Deskripsi klon karet berdasarkan karakter fisiologi lateks untuk menetapkan sistem eksploitasi yang sesuai. Jurnal Penelitian Karet, 22(1), 27-40.

Sumarmadji., Karyudi., \& Siregar, T.H.S. (2006). Rekomendasi sistem eksploitasi pada klon quick dan slow starter serta penggunaan irisan ganda untuk meningkatkan produktivitas tanaman karet. Prosiding Lokakarya Nasional Budidaya Tanaman Karet. Medan, Indonesia: Pusat Penelitian Karet.
Sumarmadji., Atminingsih., \& Karyudi. (2008). Konsep penyadapan klon slow stater dengan stimulan gas etilen dan irisan pendek ke arah atas sejak awal sadap. Prosiding Lokakarya Agribisnis Karet 2008 (p. 1375-1386). Yogyakarta, Indonesia: Pusat Penelitian Karet.

Sumarmadji. (2009). Perakitan sistem eksploitasi tanaman karet dengan siklus ekonomi dipersingkat. Laporan Akhir Tahun Penelitian APBN tahun 2009. Medan, Indonesia: Balai Penelitian Sungei Putih, Pusat Penelitian Karet.

Thomas, W., \& Boerhendhy, I. (1988). Hubungan neraca air tanah dengan produksi karet klon GT 1 dan PR 261. Bull Perkebunan Rakyat, 4(1), 15-18.

Wibowo, S.A., \& Sumarmadji. (2005). Pisau sadap yang mendukung sistem eksploitasi baru EXPEX-315. Prosiding Lokakarya Nasional Pemuliaan Tanaman Karet 2005 (p. 318-325). Medan, Indonesia: Pusat penelitian Tanaman Karet.

Woelan, S., Junaidi., \& Pasaribu, S.A. (2012). Optimasi produksi klon IRR seri 200 dengan menggunakan beberapa sistem sadap di pengujian plot promosi. Jurnal Penelitian Karet, 30(2), 75-85. https://doi.org/ $10.22302 /$ ppk.jpk.v30i2.124

Woelan, S., Sayurandi., \& Pasaribu, S.A. (2013). Karakter fisiologi, anatomi, pertumbuhan dan hasil lateks klon IRR Seri 300. Jurnal Penelitian Karet, 31(1), 1-12. https://doi.org/ 10.22302/ppk.jpk.v31i1.128 